\title{
Redescription of Batasio merianiensis, a catfish (Teleostei: Bagridae) from northeastern India
}

\author{
Heok Hee $\mathrm{Ng}$
}

Raffles Museum of Biodiversity Research, Department of Biological Sciences, National University of Singapore, 6 Science Drive 2, \# 03-01, Singapore 117546

Email: dbsnhh@nus.edu.sg

Date of online publication 26 May 2009 ISSN 0974-7907 (online) | 0974-7893 (print)

Editor: W. Vishwanath

\section{Manuscript details:}

Ms \# 02177

Received 08 April 2009

Final received 15 April 2009

Finally accepted 19 May 2009

Citation: Ng, H.H. (2009). Redescription of Batasio merianiensis, a catfish (Teleostei: Bagridae) from northeastern India. Journal of Threatened Taxa 1(5): 253-256.

Copyright: $\odot$ Heok Hee Ng 2009. Creative Commons Attribution 3.0 Unported License. JoTT allows unrestricted use of this article in any medium for non-profit purposes, reproduction and distribution by providing adequate credit to the authors and the source of publication.

Author Details: Heok HeE Ng graduated with a PhD from the University of Michigan in 2006 and has been working on the taxonomy of Asian catfishes since 1994. Now at the Raffles Museum of Biodiversity Research in Singapore, his current research focus is on sisoroid taxonomy and systematics.

Acknowledgments: I am grateful to Andrew Rao for help in obtaining specimens of $B$. merianiensis, and the following for permission to examine material under their care: David Catania (CAS), Andrew Bentley (KU), Anthony Echelle (OSUS), Douglas Nelson (UMMZ), Kelvin Lim (ZRC) and A. K. Karmakar (ZSI). This study was partially supported by the Raffles Museum of Biodiversity Research.
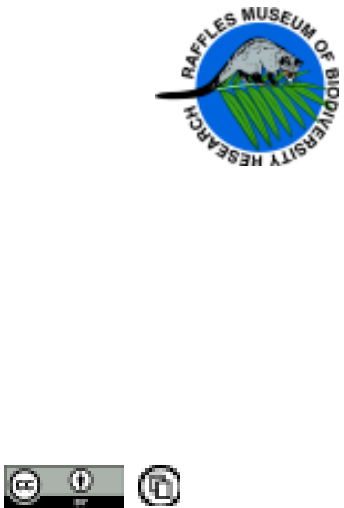

OPEN ACCESS |FREE DOWNLOAD
Abstract: The bagrid catfish Batasio merianiensis was described from only the holotype collected in the Brahmaputra River drainage, Assam, northeastern India. This poorly known catfish is rediagnosed and redescribed on the basis of fresh material in this study. Batasio merianiensis is diagnosed from congeners in having a combination of the following characters: length of adipose-fin base 16.9-22.2 \% SL, dorsal fin when appressed not reaching anterior origin of adipose fin, body depth at anus $15.2-18.4 \%$ SL, caudal peduncle depth $9.7-11.5 \%$ SL, eye diameter $18.3-25.9 \% \mathrm{HL}$, vertical dark brown bars on head and body, and absence of dark mid-dorsal stripe.

Keywords: Brahmaputra River, Siluriformes, South Asia

\section{INTRODUCTION}

Members of the genus Batasio are small, laterally compressed bagrid catfishes generally found in fast-flowing streams and rivers throughout South and mainland Southeast Asia. They are diagnosed from other confamilials in possessing large sensory pores on the head, narrow mental region, a pair of prominent posterior processes on the anterior part of the vomer, transversely elongated, bar-like entopterygoid, and the close contact of the metapterygoid with the quadrate (Mo 1991). They have a (sub-Himalayan) distribution ranging from the Indus River drainage to the west, the short, coastal rivers draining the eastern face of the Annam Cordilleras to the east, and the Perak River drainage to the south. Recent studies ( $\mathrm{Ng}$ 2008) have recognized sixteen valid species of Batasio: B. batasio, B. tengana, B. affinis, B. fluviatilis, B. dayi, B. merianiensis, B. travancoria, B. pakistanicus, B. tigrinus, B. elongatus, B. sharavatiensis, B. macronotus, B. fasciolatus, B. spilurus, $B$. feruminatus, and $B$. procerus. Of these sixteen species, half of them have been described within the last ten years, highlighting the amount of hidden diversity within the group. Batasio merianiensis (Chaudhuri 1913) is a species from the Brahmaputra River drainage in Assam (northeastern India) that is known only from the holotype. Recently, I was able to obtain fresh material from the Brahmaputra River drainage in Assam referable to this species. As the original description of this poorly known species is only based on the holotype, I rediagnose and redescribe Batasio merianiensis on the basis of this material.

\section{MATERIAL AND METHODS}

Measurements were made point-to-point with dial calipers and recorded to $0.1 \mathrm{~mm}$. All measurements and counts follow $\mathrm{Ng} \&$ Kottelat (2001). Asterisks after meristic data indicate value for holotype. Institutional codes follow Ferraris (2007). Meristic values with an asterisk indicate those for the holotype.

\section{Batasio merianiensis (Chaudhuri, 1913) (Image $1 \&$ Fig. 1)}

Macrones merianiensis Chaudhuri, 1913: 253, Pl. 9 (Figs. 1, 1a-b) [type locality: pond at Mariani Junction]

Material examined: holotype, $65.7 \mathrm{~mm}$ SL; India: Assam, pond at Mariani Junction, Assam, India, ZSI F7781/1. UMMZ 248780 (13) 46.8-75.5mm SL; ZRC 51880 (7), 49.5-59.8mm SL; India: Assam, Gurfhula River, approximately $16 \mathrm{~km} \mathrm{NW}$ of Kokrajhar, in the vicinity of Kumapara.

Diagnosis: Batasio merianiensis is distinguished from congeners in having a combination of the following characters: length of adipose-fin base $16.9-22.2 \%$ SL, dorsal fin when appressed not reaching anterior origin of adipose fin, body depth at anus 15.2-18.4\% SL, caudal peduncle depth 9.7-11.5\% SL, eye diameter 18.3-25.9\% HL, vertical dark 


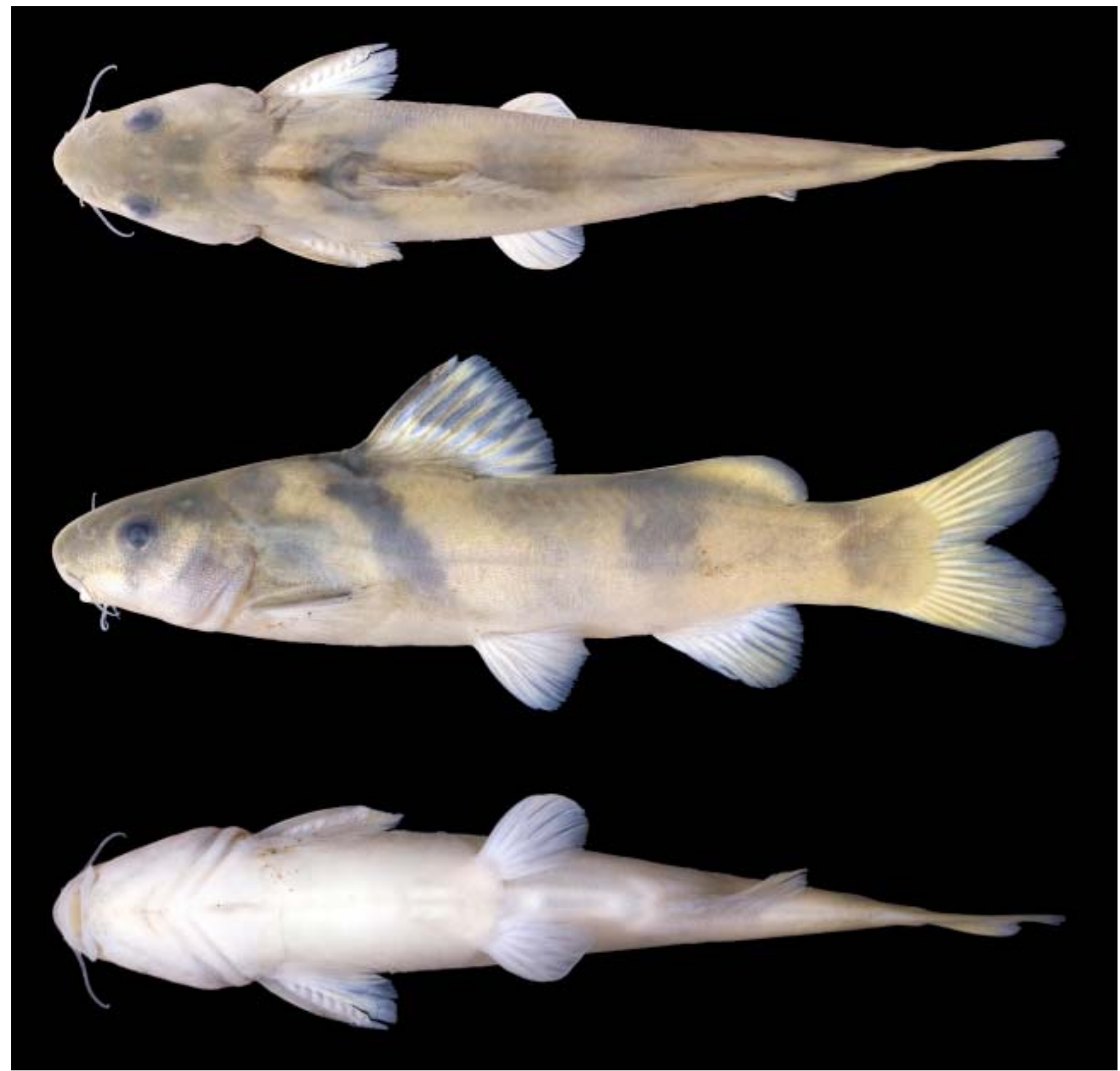

Image 1. Batasio merianiensis, UMMZ 248780, $75.7 \mathrm{~mm}$ SL; dorsal, lateral and ventral views.

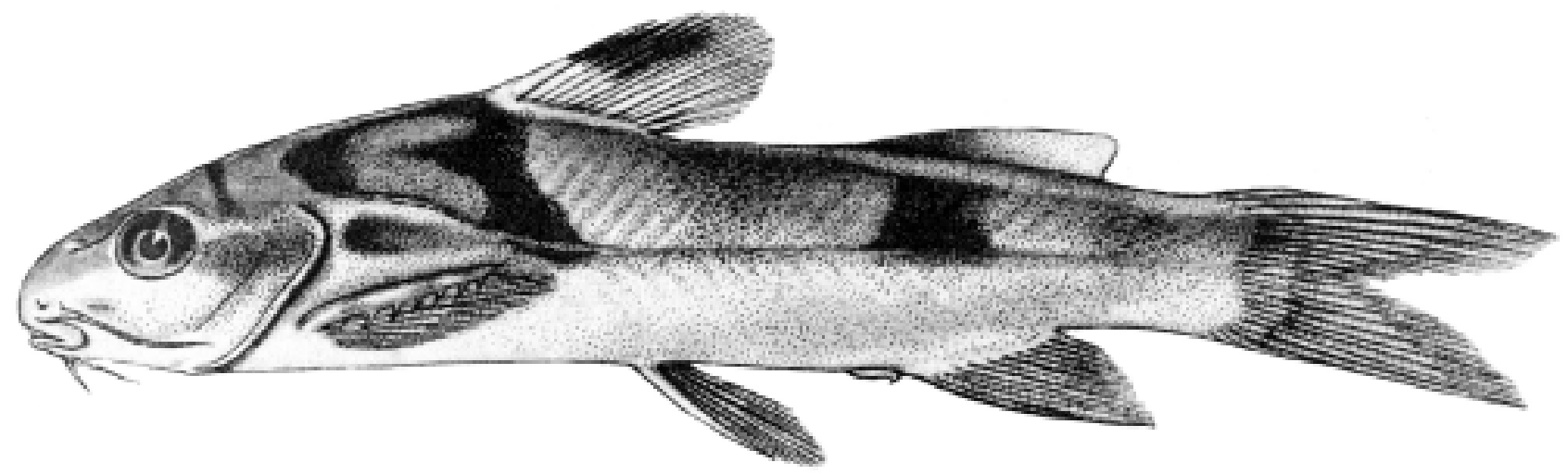

Figure 1. Batasio merianiensis: illustration of the holotype from Chaudhuri (1913: PI. 9, Fig. 1). 
Table 1. Biometric data for Batasio merianiensis $(n=21)$

\begin{tabular}{|c|c|c|c|}
\hline & Holotype & Range & Mean $\pm S D$ \\
\hline \multicolumn{4}{|l|}{$\% S L$} \\
\hline Predorsal length & 38.8 & $36.6-40.5$ & $37.7 \pm 1.31$ \\
\hline Preanal length & 67.9 & $66.3-68.2$ & $67.4 \pm 0.60$ \\
\hline Prepelvic length & 50.2 & $47.6-51.3$ & $49.9 \pm 1.13$ \\
\hline Prepectoral length & 22.5 & $21.4-25.7$ & $23.1 \pm 1.25$ \\
\hline Length of dorsal-fin base & 14.8 & $14.8-17.3$ & $16.2 \pm 0.78$ \\
\hline Dorsal-spine length & 16.6 & $13.5-16.7$ & $15.2 \pm 0.93$ \\
\hline Length of anal-fin base & 13.5 & $13.0-18.0$ & $15.2 \pm 1.29$ \\
\hline Pelvic-fin length & 16.9 & $12.3-16.9$ & $13.9 \pm 1.35$ \\
\hline Pectoral-fin length & 19.1 & $15.4-19.1$ & $17.2 \pm 1.10$ \\
\hline Pectoral-spine length & 16.3 & $12.2-16.3$ & $13.9 \pm 1.07$ \\
\hline Caudal-fin length & Damaged & $21.2-25.0$ & $22.6 \pm 1.06$ \\
\hline Length of adipose-fin base & 22.2 & $16.9-22.2$ & $19.7 \pm 1.55$ \\
\hline Dorsal to adipose distance & 13.9 & $13.9-17.4$ & $15.9 \pm 1.00$ \\
\hline Post-adipose distance & 14.3 & $13.4-15.5$ & $14.3 \pm 0.69$ \\
\hline Caudal peduncle length & 17.7 & $16.4-19.5$ & $17.5 \pm 0.85$ \\
\hline Caudal peduncle depth & 10.5 & $9.7-11.9$ & $10.7 \pm 0.65$ \\
\hline Body depth at anus & 17.4 & $15.2-18.4$ & $16.8 \pm 1.05$ \\
\hline Head length & 24 & $24.0-26.5$ & $25.6 \pm 0.63$ \\
\hline Head width & 15.2 & $13.5-16.2$ & $15.2 \pm 0.77$ \\
\hline Head depth & 17.2 & $16.3-19.3$ & $17.3 \pm 0.96$ \\
\hline \multicolumn{4}{|l|}{$\% \mathrm{HL}$} \\
\hline Snout length & 39.2 & $36.7-40.9$ & $38.5 \pm 1.22$ \\
\hline Interorbital distance & 25.9 & $25.9-31.5$ & $29.1 \pm 1.58$ \\
\hline Eye diameter & 25.9 & $18.3-25.9$ & $21.5 \pm 1.52$ \\
\hline Nasal barbel length & 25.9 & $9.4-25.9$ & $16.2 \pm 4.12$ \\
\hline Maxillary barbel length & 52.5 & $36.8-54.5$ & $46.4 \pm 5.74$ \\
\hline Inner mandibular barbel length & 10.8 & 8.4-13.3 & $11.4 \pm 1.68$ \\
\hline Outer mandibular barbel length & 14.6 & $14.3-23.2$ & $18.5 \pm 2.88$ \\
\hline
\end{tabular}

brown bars on head and body, and absence of dark mid-dorsal stripe.

Description: Morphometric data as in Table 1. Body moderately compressed. Dorsal profile rising evenly and somewhat steeply from tip of snout to origin of dorsal fin, then sloping gently ventrally from there to end of caudal peduncle. Ventral profile flat to anal-fin base, then sloping gently dorsally from there to end of caudal peduncle. Skin smooth. Lateral line complete and midlateral. Vertebrae $18+18=36(n=1)$, $18+19=37(n=1), 19+18=37(n=14)$ or $19+19=38(n=4)$.

Head compressed and narrow. Bony elements of dorsal surface of head covered with thin skin. Anterior nostrils tubular, separated from posterior nostrils by distance of twothirds eye diameter. Eye ovoid, horizontal axis longest; located entirely in dorsal half of head.

Mouth inferior, premaxillary tooth band not exposed when mouth is closed. Oral teeth small and villiform, in irregular rows on all tooth-bearing surfaces. Premaxillary tooth band rounded, of equal width throughout. Dentary tooth band much narrower than premaxillary tooth band at symphysis, tapering laterally.

Barbels in four pairs. Maxillary barbel short and slender, extending to half of distance between its base and base of pectoral spine. Nasal barbel slender, extending to anterior orbital margin. Inner mandibular-barbel origin close to midline, extending to vertical through anterior orbital margin. Outer mandibular barbel originating posterolateral of inner mandibular barbel, extending to vertical through middle of orbit.

Dorsal fin with spinelet, spine, and $7(n=21)$ rays. Origin of dorsal fin at point through anterior two-fifths of body. Dorsalfin margin convex. Dorsal-fin spine short, straight and slender, posterior edge with low irregular serrations.

Pectoral fin with stout spine, sharply pointed at tip, and $7^{*}$ $(n=2)$ or $8(n=19)$ rays. Anterior spine margin smooth; posterior spine margin with 6-7 large serrations along entire length. Pectoral-fin margin straight anteriorly, convex posteriorly.

Pelvic-fin origin at vertical through posterior end of dorsalfin base, with i,5 $(n=21)$ rays and slightly convex margin; tip of appressed fin not reaching anal-fin origin. Anus and urogenital openings located at vertical through middle of appressed pelvic fin.

Adipose fin with slightly convex margin for entire length, fin base approximately same length as anal-fin base. Origin of anal-fin base slightly posterior to origin of adipose-fin base, with iii,9 $(n=1)$, iv, $8^{*}(n=8)$, iv,9 $(n=10)$, iv, $10(n=1)$ or $v, 8$ $(\mathrm{n}=1)$ rays and convex distal margin.

Caudal peduncle of moderate depth. Caudal fin deeply forked, with i,7,8,i $(n=21)$ principal rays; upper and lower lobes slightly rounded. Procurrent rays extend only slightly anterior to fin base.

Coloration: In $70 \%$ ethanol: body and head light grayish brown, with four vertical dark brown bars: one on head passing through eye; second running obliquely anterior to dorsal fin, terminating just below lateral line; third below adipose-fin origin, terminating at lateral line; last at base of caudal fin. Faint dark, saddle-shaped patches present between dorsal-and adipose-fin bases, and on caudal peduncle immediately below posterior end of adipose-fin base. Ventral surfaces paler in color. Humeral region in area of swimbladder with scattered melanophores, conferring a slightly darker appearance. Pectoral, pelvic and anal fins hyaline, with scattered melanophores on fin rays. Dorsal fin hyaline, with dark brown subdistal ovoid patch covering spine and parts of first 3-4 branched dorsal rays.

Distribution: Known from the Brahmaputra River drainage in Assam, northeastern India.

\section{Discussion}

Four other species of Batasio are recorded from the Brahmaputra River drainage (Ng 2006): B. batasio, B. fasciolatus, B. spilurus, and B. tengana. Batasio merianiensis is distinguished from all of these species except $B$. fasciolatus in having dark vertical bars on the head and body (vs. such marks absent). It differs from B. fasciolatus in having a shorter adipose-fin base (16.9-22.2\% SL vs. 24.5-25.3; dorsal fin when appressed not reaching vs. overlapping the anterior origin of the adipose fin) and fewer vertical bars (four vs. six) on the body. Other characters that may be useful in distinguishing the two species include a more slender body (depth at anus $15.2-18.4 \%$ SL vs. 18.1-20.3) and larger eye (diameter $18.3-25.9 \%$ HL vs. 16.518.8) for B. merianiensis, although these two characters are slightly overlapping and may not be useful all the time. Batasio merianiensis further differs from B. batasio in having a shorter adipose-fin base (16.9-22.2\% SL vs. 24.8-26.5) and deeper caudal peduncle $(9.7-11.5 \%$ SL vs. $8.2-8.8)$, and from both $B$. spilurus and B. tengana in having the adipose-fin base longer than (vs. shorter than) the anal-fin base (16.9-22.2\% SL vs. 12.6-17.5) and the absence (vs. presence) of a dark mid-dorsal stripe.

In previous comparisons with only the holotype of $B$. merianiensis, the length of the pectoral-fin spine was used as a diagnostic character in distinguishing this species from $B$. fasciolatus (16.3\% SL vs. 12.7-14.3; Ng, 2006). However, data from the fresh material of B. merianiensis $(12.2-15.0 \% \mathrm{SL})$ does 
not support the diagnostic value of this character.

Although the locality from which the fresh material was obtained is nearer the type locality of B. fasciolatus $(160 \mathrm{~km}$ to the west-northwest) than that of $B$. fasciolatus ( $400 \mathrm{~km}$ to the east), it is diagnosable as being conspecific with $B$. merianiensis when compared to the illustration in the original description (Fig. 2), as the color pattern and size of the adipose fin indicates. Among congeners outside of the Brahmaputra River drainage, the color pattern of B. merianiensis is most similar to B. affinis (from the Irrawaddy, Sittang and Ataran River drainages in Myanmar) and B. tigrinus (from the Mae Klong River drainage in western Thailand). However, B. merianiensis can be distinguished from both species in having a shorter adiposefin base (16.9-22.2\% SL vs. 23.9-29.1). The appressed dorsal fin in $B$. merianiensis also does not reach (vs. overlapping in $B$. affinis) the anterior origin of the adipose fin. Batasio merianiensis further differs from B. tigrinus in having a more slender body (depth at anus $15.2-18.4 \%$ SL vs. 18.4-20.8).

\section{Comparative material}

Batasio batasio: CAS-SU 34847 (3), 58.2-69.0 mm SL; India: West Bengal, Mahananda River at Siliguri. UMMZ 209009 (1), 54.8mm SL; Bangladesh: Chittagong, Koilla Khal (creek), $9.7 \mathrm{~km} \mathrm{E}$ of Feni-Chittagong highway on road to Ramgarh, $22^{\circ} 55^{\prime} \mathrm{N} \& 91^{\circ} 36^{\prime} \mathrm{E}$. ZRC 40570 (10), 53.4-67.8mm SL; India: Assam, Dibrugarh.

B. fasciolatus: UMMZ 244798 (holotype), 67.0mm SL; UMMZ 244799 (1 paratype), 70.6mm SL; India: West Bengal, market at Malbazar, 26 $32^{\prime} 30^{\prime \prime} \mathrm{N} \& 88^{\circ} 44^{\prime} 17^{\prime \prime} \mathrm{E}$. BMNH 1988.4.11.14 (1 paratype), 50.1mm SL; India: West Bengal, Balason River at Digana, near Panighata, $20 \mathrm{~km}$ from Siliguri. UMMZ 244797 (1 paratype), 57.5mm SL; India: West Bengal, Tista River at Tista barrage, $26^{\circ} 45^{\prime} 10^{\prime \prime} \mathrm{N} \& 88^{\circ} 344^{\prime} 11^{\prime \prime} \mathrm{E}$.

B. tengana: UMMZ 244796 (neotype), $43.4 \mathrm{~mm}$ SL; India: West Bengal, Tista River at Tista barrage; $26^{\circ} 45^{\prime} 10^{\prime \prime} \mathrm{N} \&$ 88 34'11"E. KU 28534 (1), 31.5 mm SL; KU 35240 (5), 30.439.4 mm SL; KU 35256, 53.5mm SL; Nepal: Saptari/Sunsari, purchased at Kosi barrage, $26^{\circ} 31^{\prime} 30^{\prime \prime N} \& 86^{\circ} 56^{\prime} 00^{\prime} \mathrm{E}$. KU
28685 (1), 36.0mm SL; Nepal: Kanchanpur, Chandhar River, confluence of three rivers (Chaudhar, Bahuri, Gobraiya) at Royal Shuklaa Phantaa Wildlife Reserve, $28^{\circ} 43^{\prime} 00^{\prime N}$ \& 80¹2'00"E. OSUS 17365 (2), 35.8-36.6mm SL; Nepal: Nawalparasi, Narayani River at Toadi Ghat. OSUS 15812 (2), 43.8-45.9mm SL; Nepal: Nawalparasi, borrow ditch west of Tribeni.

B. spilurus: ZRC 49133 (holotype), 42.0 mm SL; ZRC 50201 (1 paratype), $40.5 \mathrm{~mm}$ SL; India: Assam, Dibrugarh district, $27^{\circ} 29^{\prime} \mathrm{N} \& 94^{\circ} 54^{\prime} \mathrm{E}$.

Additional material examined is listed in $\mathrm{Ng}$ (2006), $\mathrm{Ng}$ \& Kottelat (2007) and $\mathrm{Ng}$ (2008).

\section{References}

Chaudhuri, B.L. (1913). Zoological results of the Abor Expedition, 1911-12. XVIII. Fish. Records of the Indian Museum 8(3): 243-257, Pls. 7-9.

Ferraris, C.J. Jr. (2007). Checklist of catfishes, recent and fossil (Osteichthyes: Siluriformes) and catalogue of siluriform primary types. Zootaxa 1418: 1-628.

Mo, T.-P. (1991). Anatomy, relationships and systematics of the Bagridae (Teleostei: Siluroidei) with a hypothesis of siluroid phylogeny. Theses Zoologicae 17. Koeltz, Koenigstein, 216pp.

Ng, H.H. (2006). The identity of Batasio tengana (Hamilton, 1822), with the description of two new species of Batasio from north-eastern India (Teleostei: Bagridae). Journal of Fish Biology 68(Supplement A): $101-118$

Ng, H.H. (2008). Batasio procerus, a new species of catfish from northern Myanmar (Siluriformes: Bagridae). Ichthyological Exploration of Freshwaters 19(1): 1-6.

Ng, H. H. \& M. Kottelat (2001). A review of the genus Batasio (Teleostei: Bagridae) in Indochina, with the description of B. tigrinus sp. n. from Thailand. Revue Suisse de Zoologie 108(3): 495-511.

Ng, H.H. \& M. Kottelat (2007). Batasio feruminatus, a new species of bagrid catfish from Myanmar (Siluriformes: Bagridae), with notes on the identity of B. affinis and B. fluviatilis. Ichthyological Exploration of Freshwaters 18(4): 289-300. 